\title{
Fire regimes in eastern coastal fynbos: Imperatives and thresholds in managing for diversity
}

\begin{tabular}{|c|c|}
\hline \multicolumn{2}{|c|}{$\begin{array}{l}\text { Authors: } \\
\text { Tineke Kraaij }^{1,2} \\
\text { Richard M. Cowling }{ }^{2} \\
\text { Brian W. van Wilgen }\end{array}$} \\
\hline $\begin{array}{l}\text { Affiliations: } \\
{ }^{1} \text { South African } \\
\text { Parks, Garden } \\
\text { Scientific Servi } \\
\text { South Africa }\end{array}$ & $\begin{array}{l}\text { National } \\
\text { Route } \\
\text { ces, }\end{array}$ \\
\hline $\begin{array}{l}{ }^{2} \text { Department o } \\
\text { Nelson Mande } \\
\text { Metropolitan } ~ \\
\text { South Africa }\end{array}$ & $\begin{array}{l}\text { f Botany, } \\
\text { Jniversity, }\end{array}$ \\
\hline $\begin{array}{l}{ }^{3} \text { CSIR Natural } \\
\text { and the Enviro } \\
\text { Stellenbosch, } 5\end{array}$ & $\begin{array}{l}\text { Resources } \\
\text { nment, } \\
\text { South Africa }\end{array}$ \\
\hline $\begin{array}{l}{ }^{4} \text { Centre for Inv } \\
\text { Department of } \\
\text { and Zoology, S } \\
\text { University, Sou }\end{array}$ & $\begin{array}{l}\text { asion Biology, } \\
\text { f Botany } \\
\text { tellenbosch } \\
\text { th Africa }\end{array}$ \\
\hline $\begin{array}{l}\text { Corresponden } \\
\text { Tineke Kraaij }\end{array}$ & ce to: \\
\hline $\begin{array}{l}\text { Email: } \\
\text { tineke.kraaij@ }\end{array}$ & sanparks.org \\
\hline $\begin{array}{l}\text { Postal address } \\
\text { PO Box 176, Se } \\
\text { South Africa }\end{array}$ & edgefield 6573, \\
\hline $\begin{array}{l}\text { Dates: } \\
\text { Received: } 25 \mathrm{~J} \\
\text { Accepted: } 10 \\
\text { Published: } 15 \\
\text { Republished: } 0\end{array}$ & $\begin{array}{l}\text { uly } 2012 \\
\text { Mec. } 2012 \\
\text { Mar. } 2013 \\
2 \text { Apr. } 2013\end{array}$ \\
\hline $\begin{array}{l}\text { Note: } \\
\text { This article wa } \\
\text { with the corre } \\
\text { Brian W. van W }\end{array}$ & $\begin{array}{l}\text { s republished } \\
\text { ct affiliation for } \\
\text { Vilgen. }\end{array}$ \\
\hline $\begin{array}{l}\text { How to cite th } \\
\text { Kraaij, T., Cowl } \\
\text { Van Wilgen, B. } \\
\text { regimes in eas } \\
\text { fynbos: Impera } \\
\text { thresholds in n } \\
\text { diversity', Koec } \\
\text { Art. \#1104, } 9 \text { p } \\
\text { dx.doi.org/10. } \\
\text { v55i1.1104 }\end{array}$ & $\begin{array}{l}\text { is article: } \\
\text { ing, R.M. \& } \\
\text { W., 2013, 'Fire } \\
\text { tern coastal } \\
\text { atives and } \\
\text { nanaging for } \\
\text { doe 55(1), } \\
\text { pages. http:// } \\
\text { 4102/koedoe. }\end{array}$ \\
\hline $\begin{array}{l}\text { Copyright: } \\
\text { C 2013. The A } \\
\text { Licensee: AOSI } \\
\text { OpenJournals. } \\
\text { is licensed und } \\
\text { Creative Comn } \\
\text { Attribution Lic }\end{array}$ & $\begin{array}{l}\text { uthors. } \\
\text { IS } \\
\text { This work } \\
\text { ler the } \\
\text { nons } \\
\text { ense. }\end{array}$ \\
\hline 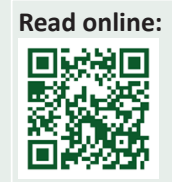 & $\begin{array}{l}\text { Scan this QR } \\
\text { code with your } \\
\text { smart phone or } \\
\text { mobile device } \\
\text { to read online. }\end{array}$ \\
\hline
\end{tabular}

Until recently, fire ecology was poorly understood in the eastern coastal region of the Cape Floral Kingdom (CFK), South Africa. Rainfall in the area is aseasonal and temperatures are milder than in the winter-rainfall and drier inland parts of the CFK, with implications for the management of fire regimes. We synthesised the findings of a research programme focused on informing ecologically sound management of fire in eastern coastal fynbos shrublands and explored potential east-west trends at the scales of study area and CFK in terms of fire return interval (FRI) and fire season. FRIs (8-26 years; 1980-2010) were comparable to those elsewhere in the CFK and appeared to be shorter in the eastern Tsitsikamma than in the western Outeniqua halves of the study area. Proteaceae juvenile periods (4-9 years) and postfire recruitment success suggested that for biodiversity conservation purposes, FRIs should be $\geq 9$ years in eastern coastal fynbos. Collectively, findings on the seasonality of actual fires and the seasonality of fire danger weather, lightning and post-fire proteoid recruitment suggested that fires in eastern coastal fynbos are not limited to any particular season. We articulated these findings into ecological thresholds pertaining to the different elements of the fire regime in eastern coastal fynbos, to guide adaptive management of fire in the Garden Route National Park and elsewhere in the region.

Conservation implications: Wildfires are likely to remain dominant in eastern coastal fynbos, whilst large-scale implementation of prescribed burning is unattainable. Fires occurring in any season are not a reason for concern, although other constraints remain: the need for sufficient fire intensity, safety requirements, and integration of fire and invasive alien plant management.

\section{Introduction}

Fire is instrumental in maintaining the species-rich and endemic-rich fynbos shrublands (Myers et al. 2000) of the Cape Floral Kingdom (CFK) of South Africa (Kruger \& Bigalke 1984). Fire is the dominant natural disturbance in fynbos and managing fynbos equates to managing fire. The fire ecology of fynbos has been well researched in the western, winter-rainfall part of the CFK (Kruger \& Bigalke 1984; Van Wilgen \& Viviers 1985) and in the drier inland mountains (Bond, Vlok \& Viviers 1984; Midgley 1989; Seydack, Bekker \& Marshall 2007) but was, until recently, poorly understood in the eastern coastal part of the CFK. The climate of the latter is milder with reduced seasonal extremes in temperature, whilst rainfall occurs year-round. As shown by Heelemann et al. (2008) in the inland fynbos of the eastern CFK, overstorey proteoids (non-sprouting, slow-maturing, serotinous Proteaceae) show weak seasonal effects on post-fire recruitment, a consequence of a non-seasonal rainfall and fire regime. We expected similar patterns in our region, as well as faster plant growth and maturation rates of proteoids, a consequence of the region's relatively benign climate. These phenomena will have important implications for the management of fire regimes.

The Garden Route National Park (GRNP; c. 130000 ha) was recently established in the eastern coastal part of the CFK in a landscape mosaic of indigenous forests, fire-prone fynbos shrublands and fire-sensitive plantations of invasive alien trees. The park faces considerable ecological and operational challenges pertaining to the management of fire and invasive alien plants (Kraaij, Cowling \& Van Wilgen 2011). A recent, multifaceted research programme was undertaken to inform ecologically sound management of fire in eastern coastal fynbos and entailed, (1) an assessment of the context within which fire management was practiced during the past century (Kraaij et al. 2011), (2) characterisation of the recent fire history and fire regime (1900-2010) in the area (Kraaij, Baard, Cowling, Van Wilgen \& Das 2012), (3) characterisation of the seasonality of fire weather and lightning (Kraaij, Cowling \& Van Wilgen 2012), (4) estimation of minimum fire return intervals (FRIs) from juvenile periods and post-fire recruitment success of proteoids (Kraaij et al. 2013) and (5) determination of the ecologically appropriate fire season from post-fire recruitment seasonality of proteoids (Kraaij 2012). 
Here we synthesise the findings of this research in terms of potential east-west trends within eastern coastal fynbos and at the scale of the entire CFK. Furthermore, we articulate the findings into ecological thresholds (Biggs \& Rogers 2003; Van Wilgen et al. 2011) pertaining to the different elements of the fire regime in eastern coastal fynbos, to guide adaptive management of fire in the park and elsewhere in the region.

\section{Study area}

The study area comprises the coastal slopes of the Outeniqua Mountains (east of the Touw River) and Tsitsikamma Mountains $\left(33^{\circ} 48^{\prime} \mathrm{S} 22^{\circ} 35^{\prime} \mathrm{E}-34^{\circ} 01^{\prime} \mathrm{S} 24^{\circ} 16^{\prime} \mathrm{E}\right)$, of which a large portion occurs within the GRNP (Kraaij et al. 2011). Owing to maritime influence, the climate of the area is relatively equable (Schulze 1997). Rainfall occurs throughout the year, with winter months being the driest. Mean annual rainfall increases eastwards, from $820 \mathrm{~mm}$ to $1078 \mathrm{~mm}$ in the Outeniqua and Tsitsikamma Mountains, respectively. The proportion of summer rain also increases eastwards (Schulze 1997). The fire-prone and fire-dependent vegetation of the study area largely comprises South Outeniqua Sandstone Fynbos and Tsitsikamma Sandstone Fynbos in the Outeniqua and Tsitsikamma Mountains, respectively (Rebelo et al. 2006). These are tall, medium-dense proteoid shrublands, with an ericoid-leaved shrub understorey (dominated by Ericaceae) and a prominent restioid (Restionaceae) component. More detailed accounts of the climate, vegetation and fire management history of the study area can be found elsewhere (Geldenhuys 1994; Kraaij et al. 2011, 2013; Kraaij, Cowling \& Van Wilgen 2012).

\section{Fynbos fire regimes across an east-west transect}

Kraaij et al. (2011) established that historically, plantation protection enjoyed priority over fynbos conservation, influenced by the large extent of plantations in the study area. Fynbos close to plantations has probably been compromised by short-rotation (4-8 years at times) and low-intensity burning in the past, as well as by invasion by alien trees. In terms of area burnt (1900-2010), natural (lightning-ignited) fires dominated the fire regime (59\%), particularly in the Tsitsikamma (83\%), whereas prescribed burning was relatively unimportant (Kraaij, Baard, Cowling, Van Wilgen \& Das 2012). FRIs since 1980 appeared to be shorter in the east of the study area (Tsitsikamma region, median FRI $=8.3$ years, when only complete fire intervals were considered), where rainfall and plant growth rates are higher, than in the west (Outeniqua region, median FRI = 13.2 years) (Kraaij, Baard, Cowling, Van Wilgen \& Das 2012). However, FRIs for the study area as a whole (8-26 years, considering complete and open-ended fire intervals during the period 1980-2010) were broadly comparable to those of other regions in the CFK (15-55 years - Seydack et al. 2007; 10-21 years - Van Wilgen et al. 2010), suggesting that variation is related to local or regional moisture regimes (Kruger \& Bigalke 1984; Seydack et al. 2007) rather than an east-west gradient of increasing FRIs across the CFK. This is consistent with the lack of a gradient in mean annual rainfall from east to west within the CFK (Deacon, Jury \& Ellis 1992). Proteaceae juvenile periods (4-9 years) and post-fire recruitment success (following fires in 7-year-old vegetation) suggested that for biodiversity conservation purposes, FRIs should be no less than 9 years in moist, productive fynbos (Kraaij et al. 2013). Minimum FRIs to ensure pre-fire maturation and thus successful post-fire recruitment of proteoids in the study area (Kraaij et al. 2013) were similar to those from other parts of the CFK (Van Wilgen et al. 2011).

Seasonality in fire occurrence was less pronounced in the east than in the west of the study area, with fires less concentrated in summer in the Tsitsikamma (13\% of area burnt) than in the Outeniqua region (31\%) (Kraaij, Baard, Cowling, Van Wilgen \& Das 2012). In the study area as a whole, fire occurrence was less seasonal (c. $40 \%$ of the total area burnt did so during summer-autumn) than in western (c. 75\%) and inland (c. 70\%) (Seydack et al. 2007; Van Wilgen et al. 2010) parts of the CFK, consistent with climatic gradients of increasing winter rainfall and summer drought from east to west and increasing summer evapotranspiration from the coast to the interior. The trend of increasing seasonality in fire occurrence and rainfall from east to west was not reflected in the seasonality of lightning occurrence at either the scale of study area or CFK (Kraaij, Cowling \& Van Wilgen. 2012). The east-west trend of increasing seasonality in fire occurrence was, however, reflected in the biotic post-fire recruitment response. Fire season had little consistent effect on post-fire recruitment of proteoids in the study area (Kraaij 2012), in contrast to the strong seasonal response in western (Midgley 1989; Van Wilgen \& Viviers 1985) and inland (Bond 1984; Bond et al. 1984) parts of the CFK, where summer and autumn fires result in optimal recruitment. Collectively, findings in the study area on the seasonality of actual fires (Kraaij, Baard, Cowling, Van Wilgen \& Das 2012) and the seasonality of fire danger weather, lightning (Kraaij, Cowling \& Van Wilgen 2012), as well as post-fire proteoid recruitment (Kraaij 2012) suggest that fires in eastern coastal fynbos are not limited to any particular season, and therefore management is not constrained, although the ecological requirements for adequate fire intensity (Van Wilgen et al. 2011) remain.

Significant increases in the total area burnt annually since 1980 (Kraaij, Baard, Cowling, Van Wilgen \& Das 2012) that were correlated with significant long-term increases in weather conditions conducive to the spread of fires (Kraaij, Cowling \& Van Wilgen 2012), suggest fire regime changes related to global change. Increases in fire frequency or extent (Forsyth \& Van Wilgen 2008) and in the severity of fire danger weather conditions (Wilson et al. 2010) have similarly been observed elsewhere in the CFK, although evidence is not unequivocal across all meteorological variables (e.g. relative humidity, wind run) affecting fire danger weather (Hoffman et al. 2011; Kraaij, Cowling \& Van Wilgen 2012).

\section{Managing fire for biodiversity conservation: Ecological thresholds}

Fire management practices aimed at biodiversity conservation within protected areas are often in conflict with hazard 
reduction requirements (Kraaij et al. 2011) and, where such conflict of interest exists, managers need to know the ecological thresholds within which fire may be managed. Adaptive management is based on formulating targets (or thresholds of potential concern) (Biggs \& Rogers 2003) describing acceptable variations in the elements (frequency, season, intensity, size) of fire regimes, with monitoring regularly assessing 'whether the fire regimes that arise from various forms of management remain within the specified ranges' (Van Wilgen et al. 2011). We have set provisional thresholds for eastern coastal fynbos (Table 1) and particularly in terms of two elements of the fire regime, namely fire frequency (the lower threshold for FRI) (Kraaij et al. 2013) and fire season (Kraaij 2012).

The adoption of thresholds in terms of elements of the fire regime may, at first glance, appear to imply that the fire patterns themselves are the desired outcome. However, fire patterns will ultimately manifest themselves in vegetation structure, function and composition, which are assessed in terms of thresholds related to the responses of ecosystems to fire (Van Wilgen et al. 2011). We distinguished between thresholds pertaining to fire patterns (termed 'operational thresholds' by Van Wilgen et al. 2011) and those pertaining to ecosystem responses to fires (termed 'ecosystem thresholds' by Van Wilgen et al. 2011) (Table 1), the ultimate goal being to make the links between fire patterns and ecological outcomes.

\section{Fire return interval}

Estimates of optimal fire frequencies are often based on the relationship between plant age and the rate of seed accumulation of the slowest-maturing species. In fynbos and in Australian shrublands, juvenile periods of proteoids are used as indicators of extreme lower limits for FRIs, whereas their longevity indicates extreme upper limits (Bond 1980; Gill \& McCarthy 1998). The rule of thumb generally used in fynbos to establish a lower threshold for FRI posits that half of the individuals in a population of the slowestmaturing proteoid species should have flowered in at least three successive seasons before the area may be burnt (Kruger \& Lamb 1978; Kruger 1982; Van Wilgen et al. 2011) (Table 1). Recruitment success of proteoids after fires at different intervals may also indicate the ecological suitability of FRIs.

Application of the mentioned rule of thumb to juvenile periods observed in the study area implied a minimum FRI of 9 years for moist, productive Tsitsikamma fynbos, whereas post-fire recruitment of proteoids was always successful following FRIs of 7 years (Kraaij et al. 2013). Considerable variation in juvenile periods, flowering status at given plant ages and post-fire recruitment success at given FRIs, within and between species and habitats (Kraaij et al. 2013), suggests that management should not attempt to rigidly and consistently pursue a fixed or narrow range of FRIs. Besides it being practically unattainable (Van Wilgen et al. 2010), variability in FRIs in nature is inevitable and, where fire management is aimed at conserving biodiversity, variation within established limits is desirable (Gill \& McCarthy 1998; Thuiller et al. 2007). Variation in FRI (or fire season or fire intensity) will induce variation in the density of overstorey proteoids, which, in turn, is associated with maintenance of diversity in understorey species (Cowling \& Gxaba 1990; Vlok \& Yeaton 1999).

Some of the variation in flowering status appeared to be related to local moisture regimes with FRIs being inversely related to rainfall or moisture availability. Due cognisance should therefore be taken of site-specific requirements, with drier habitats (northerly or westerly aspects or shallow soils) generally needing longer intervals between fires. Range-restricted species or habitat specialists may furthermore have very specific FRI requirements (Kruger \& Bigalke 1984). Slow-growing, high-altitude species, for example Protea grandiceps (Near Threatened) (Raimondo et al. 2009), may be slow to mature (> 10 years) (J.H.J. Vlok pers. comm., 04 February 2012) and thus require longer FRIs.

Although their primary aim was to establish a lower threshold for FRI, the results of Kraaij et al. (2013) also showed that the upper threshold for FRI is likely to be in excess of 38 years. They concurred with Van Wilgen et al. (2011) that the occurrence of very old vegetation and thus the setting of an upper threshold for FRI is not a key concern in the ecological management of fire in montane proteoid fynbos, both because old vegetation is typically limited in extent (Bond 1980; Kraaij, Baard, Cowling, Van Wilgen \& Das 2012) and because proteoid recruitment does not appear to be negatively affected by relatively long inter-fire periods (Kraaij et al. 2013).

An assessment of the historical (1980-2010) occurrence of fire in the study area found that the proposed FRI thresholds were exceeded over a greater proportion of the area burnt in the Tsitsikamma than in the Outeniqua region (Kraaij, Baard, Cowling, Van Wilgen \& Das 2012). Since 1980, $11 \%$ of the fynbos of the GRNP burnt at least once at postfire ages of $<7$ years. In these areas, proteoids have likely been locally eliminated, as post-fire recruitment success of this guild has been near zero following a 5-year FRI (Kraaij et al. 2013). Measuring against a minimum FRI threshold of 9 years resulted in much greater area exceeding this threshold, with $27 \%$ of the study area (31\% of Tsitsikamma and $15 \%$ of Outeniqua) having burnt at least once at post-fire ages of $<9$ years. In these areas, seed banks of proteoids have likely been insufficient at the time of fire to have enabled optimal post-fire recruitment. The extent to which proteoid populations may have been compromised in these areas depends on the particular species present, local moisture regimes and plant maturation rates (Kraaij et al. 2013). Identification of site and vegetation characteristics and weather conditions before and during short interval fires could provide valuable insight into whether an increase in the occurrence of such burns may be expected.

Short interval fires, which alter vegetation structure (from woody to herbaceous) (Kruger 1984; Lloret, Pausas \& 
Vilà 2003) and thus fuel dynamics, may set up negative feedback loops whereby short FRIs persist in the landscape (Richardson \& Van Wilgen 1992). Similar effects on fire regimes have occurred after invasion by alien grasses of Californian chaparral (Keeley \& Brennan 2012). In large parts of the study area, graminoid sprouters dominate, whilst proteoids are sparse or absent (Heelemann et al. 2010), notably in areas near plantations of alien pine trees (T. Kraaij, pers. obs.). This likely resulted from frequent and low intensity burning in the past, aimed at protecting timber plantations from fire (Kraaij et al. 2011). Facilitation of FRIs that would ensure the long-term persistence of proteoids in the GRNP is thus a priority for fynbos conservation management, particularly where this guild has persisted in the landscape. It is therefore important to map the distribution of species that are vulnerable to too frequent fires and to incorporate this information into the fire management plan for the area.

Thresholds may also be set for post-fire age class distributions of the vegetation (Table 1). Relatively equal age class distributions are desirable as these would provide variation in vegetation age and structure, and thus a variety of habitat types for a diversity of species, in addition to spreading out the work load over time for prescribed burning and invasive plant control (Van Wilgen et al. 2011). The distribution of post-fire vegetation age classes in the GRNP (measured in 2011) was highly skewed towards the younger age classes (Kraaij, Baard, Cowling, Van Wilgen \& Das 2012), thereby far exceeding proposed thresholds (Table 1) and upsetting invasive alien plant clearing schedules. To correct this situation, increased attempts at protection of GRNP fynbos from extensive burning would be desirable for the next few year.

\section{Fire season}

Season of fire has marked effects on floristic composition in fire-prone Mediterranean-climate shrublands (Bond 1984; Enright \& Lamont 1989; Midgley 1989). In these winterrainfall systems, summer-autumn fires lead to optimal recruitment of proteoids, which are key to the conservation of floral diversity overall. Kraaij (2012) established that seasonal patterns in post-fire recruitment of proteoids are weak in eastern coastal fynbos (good recruitment may occur after disturbance in any season), in line with the findings that fire danger weather (Kraaij, Cowling \& Van Wilgen. 2012) and fire occurrence (Kraaij, Baard, Cowling, Van Wilgen \& Das 2012) in this area are also largely aseasonal. This implies a lack of any seasonal constraint on burning, which has encouraging management implications. Managers will not have to allocate large amounts of resources to fight wildfires that are burning in what are considered ecologically undesirable seasons based on patterns from the western and inland fynbos regions; they may also conduct back burns during any season. Instead of the thresholds applicable to fire seasonality in western and inland fynbos (i.e. that $>80 \%$ of area should burn during summer-autumn and $<20 \%$ during winter-spring) (Van Wilgen et al. 2011), variability in fire season is considered desirable in eastern coastal fynbos. The thresholds we propose for the study area accordingly relate to a reasonably even distribution of fires amongst seasons (i.e. the proportion of the area burnt in any particular season should be $>10 \%$ and $<40 \%$ ) (Table 1 ).

In aseasonal environments such as the study area and southeastern Australia, there is large variation between years in the seasonality of rainfall and an unpredictable response of proteoid recruitment to season of fire. The effect of fire season on proteoids may, in the long term, be no more important than that of the timing of fire in relation to occurrence of wet and dry cycles (Bradstock \& Bedward 1992). Particularly in these unpredictable, aseasonal environments, variation in fire regimes (including fire season) is necessary to maintain plant diversity in space and time (Gill \& McCarthy 1998; Thuiller et al. 2007). The range of acceptable variation in fire seasonality that we propose is accordingly wide.

Although removal of the seasonal constraint should expand the window of opportunity and thus improve the chances of implementing prescribed burns, the ecological need for adequate fire intensity remains (Table 1) (Van Wilgen et al. 2011). Fire intensity needs to be sufficiently high to stimulate seed release and germination in serotinous (Midgley \& Viviers 1990) and large or hard-coated, soilstored seeds (Bond et al. 1990; Jefferey, Holmes \& Rebelo 1988; Knox \& Clarke 2006), but not excessive such that species with small seeds and shallow seed banks are killed (Bond, Honig \& Maze 1999). For instance, a few severely fragmented subpopulations (mostly with $<50$ individuals each) of the large-seeded, myrmecochorous Mimetes splendidus (Endangered) (Raimondo et al. 2009) occur within the study area and at least one subpopulation (at Buffelsnek) is known to have been lost as a result of low intensity fires (J.H.J. Vlok pers. comm., 04 February 2012). Furthermore, ecological requirements of fire intensity are often in conflict with safety considerations (Morrison, Buckney \& Bewick 1996; Van Wilgen et al. 2012), presenting considerable management challenges.

An assessment of the historical occurrence of fire in the study area found that fire season thresholds were not exceeded when considering the period from 1900-2010 as a whole (Kraaij, Baard, Cowling, Van Wilgen \& Das 2012). The proportional areas burnt were fairly evenly distributed amongst seasons (winter 23\%, spring 35\%, summer 19\%, autumn 22\%). Neither were the thresholds exceeded when assessed over the past 15 years (1996-2010) (cf. Van Wilgen et al. 2011), when the seasonal distribution of fires was also relatively even (winter 20\%, spring 35\%, summer 19\%, autumn 30\%). Despite the occurrence of several very large (10 000 ha) fires since 1990, fire seasonality remained within the proposed thresholds, suggesting that inappropriate season of fire generally does not jeopardise ecologically sound management of fynbos in the area.

\section{Fire management approach: Operational considerations}

Approaches to fire management in fynbos are mainly distinguished by the extent of intervention pursued, 
TABLE 1: Proposed thresholds of potential concern relating to fire management of fynbos (c. 105000 ha) in the Garden Route National Park. Thresholds pertaining to fire patterns are informed by monitoring against thresholds related to ecosystem responses to fires.

\begin{tabular}{|c|c|c|c|c|}
\hline Response type & Area of potential concern & Reason for concern & Measure & Thresholds \\
\hline \multirow[t]{7}{*}{ Fire patterns } & $\begin{array}{l}\text { Post-fire age distribution } \\
\text { will be skewed or } \\
\text { uneven. }\end{array}$ & $\begin{array}{l}\text { An unequal distribution of age classes will } \\
\text { not provide sufficient habitat for a full range } \\
\text { of species requiring access to vegetation } \\
\text { of different ages, and will not allow for } \\
\text { manageable amounts of vegetation to be } \\
\text { scheduled for prescribed burning over time. }\end{array}$ & $\begin{array}{l}\text { Proportion of area in the following } \\
\text { post-fire age classes: } 0-6,7-12,>12 \\
\text { years. }\end{array}$ & $\begin{array}{l}\text { The proportion of area in each age } \\
\text { class should be }>25 \% \text { and }<50 \% \text {. }\end{array}$ \\
\hline & $\begin{array}{l}\text { Large areas will go } \\
\text { without fire for too long. }\end{array}$ & $\begin{array}{l}\text { Fires in older vegetation will lead to poor } \\
\text { post-fire reproduction in groups of plants } \\
\text { prone to senescence (e.g. serotinous } \\
\text { Proteaceae). }\end{array}$ & $\begin{array}{l}\text { Proportion of the area }>40 \text { years } \\
\text { post-fire. }\end{array}$ & $\begin{array}{l}\text { Proportion of the area }>40 \text { years } \\
\text { post-fire should be }<20 \% \text {. }\end{array}$ \\
\hline & $\begin{array}{l}\text { Large areas will burn too } \\
\text { frequently. }\end{array}$ & $\begin{array}{l}\text { Fires in populations of immature serotinous } \\
\text { Proteaceae will lead to poor post-fire } \\
\text { regeneration, population declines and } \\
\text { local extinction. }\end{array}$ & $\begin{array}{l}\text { Fire return intervals assessed over the } \\
\text { past } 30 \text { years. }\end{array}$ & $\begin{array}{l}\text { Fire return intervals should be } \geq 9 \\
\text { years on }>80 \% \text { of the area overall } \\
\text { and on }>90 \% \text { of the area containing } \\
\text { proteoids (once mapped). }\end{array}$ \\
\hline & $\begin{array}{l}\text { Fires will consistently } \\
\text { occur in a particular } \\
\text { season(s). }\end{array}$ & $\begin{array}{l}\text { A lack of variation in fire season in an } \\
\text { environment where variation is the norm } \\
\text { may consistently promote some species over } \\
\text { others thereby reducing diversity. }\end{array}$ & $\begin{array}{l}\text { The proportion of the area that burns } \\
\text { in any particular season over the past } \\
15 \text { years. }\end{array}$ & $\begin{array}{l}\text { The area burnt in each season (winter } \\
\text { - June, July, Aug.; spring - Sept., } \\
\text { Oct., Nov.; summer - Dec., Jan., Feb.; } \\
\text { autumn - Mar., Apr., May) should be }> \\
10 \% \text { and }<40 \% \text {. }\end{array}$ \\
\hline & $\begin{array}{l}\text { Large areas will burn in } \\
\text { fires of low intensity or } \\
\text { extremely high intensity. }\end{array}$ & $\begin{array}{l}\text { Low fire intensity will fail to stimulate seed } \\
\text { release in serotinous plants and germination } \\
\text { of large or hard-coated, soil-stored seeds. }\end{array}$ & $\begin{array}{l}\text { Proportion of the area that burnt } \\
\text { under low fire danger conditions } \\
\text { (FDI } \leq 5) \text { over the past } 15 \text { years. }\end{array}$ & Should be $<25 \%$. \\
\hline & & $\begin{array}{l}\text { Extremely high fire intensity will kill small- } \\
\text { seeded species with shallow seed banks (e.g. } \\
\text { Erica spp.) and increase post-fire soil erosion. }\end{array}$ & $\begin{array}{l}\text { Proportion of the area that burnt with } \\
\text { excessive fuel loads (e.g. due to alien } \\
\text { plant infestations) under high fire } \\
\text { danger conditions. }\end{array}$ & \\
\hline & $\begin{array}{l}\text { Instead of a similar area } \\
\text { being burnt each year, } \\
\text { a few large fires, or, } \\
\text { alternately, a large number } \\
\text { of small fires could occur. }\end{array}$ & $\begin{array}{l}\text { Too many small fires will be difficult and } \\
\text { costly to manage. Edge effects (for example } \\
\text { predation of seeds by rodents) will be } \\
\text { greater with many small fires. } \\
\text { Very large fires ( }>10 \% \text { of the area of the } \\
\text { Park) will upset the desired goal of } \\
\text { maintaining an even distribution of post-fire ages. }\end{array}$ & $\begin{array}{l}\text { The distribution of areas of all } \\
\text { individual fires over the past } 15 \text { years. } \\
\text { Adjoining fires that burn in the same } \\
\text { season of the same year should be } \\
\text { counted as one fire. }\end{array}$ & $\begin{array}{l}\text { The proportion area burnt in fires }> \\
1000 \text { ha should be }>80 \% \text {. } \\
\text { Single fires should not exceed } \\
20000 \text { ha. }\end{array}$ \\
\hline \multirow[t]{4}{*}{$\begin{array}{l}\text { Ecosystem } \\
\text { responses to fire }\end{array}$} & $\begin{array}{l}\text { Insufficient individuals in } \\
\text { populations of serotinous } \\
\text { Proteaceae will reach } \\
\text { maturity and set seed prior } \\
\text { to fire. }\end{array}$ & $\begin{array}{l}\text { Fires that occur in relatively immature } \\
\text { populations will lead to population declines } \\
\text { or local extinction. }\end{array}$ & $\begin{array}{l}\text { Proportion of individual populations } \\
\text { that have flowered for at least three } \\
\text { successive seasons. }\end{array}$ & $\begin{array}{l}\text { At least } 50 \% \text { of individuals in a } \\
\text { monitored population should have } \\
\text { flowered for at least three successive } \\
\text { seasons before a fire. }\end{array}$ \\
\hline & $\begin{array}{l}\text { Too many individuals in } \\
\text { populations of serotinous } \\
\text { Proteaceae will reach } \\
\text { senescence prior to fire. }\end{array}$ & $\begin{array}{l}\text { Fires that occur in senescent populations will } \\
\text { lead to population declines or local extinction. }\end{array}$ & $\begin{array}{l}\text { Proportion of individual populations } \\
\text { that show advanced signs of } \\
\text { senescence. }\end{array}$ & $\begin{array}{l}\text { No more than } 25 \% \text { of individuals in } \\
\text { a monitored population should have } \\
\text { advanced signs of senescence before } \\
\text { a fire. }\end{array}$ \\
\hline & $\begin{array}{l}\text { Post-fire recruitment in } \\
\text { populations of serotinous } \\
\text { Proteaceae could be } \\
\text { inadequate to replace } \\
\text { pre-fire populations. }\end{array}$ & $\begin{array}{l}\text { Fires in ecologically disadvantageous } \\
\text { conditions (either post-fire age, low fire } \\
\text { intensity, drought or exposure to high levels } \\
\text { of seed predation) could lead to failure of } \\
\text { adequate populations to establish after fire, } \\
\text { leading to population declines of } \\
\text { local extinction. }\end{array}$ & $\begin{array}{l}\text { The ratio of seedlings to parent plants } \\
\text { measured } 1-2 \text { years after a fire. }\end{array}$ & $\begin{array}{l}\text { Seedling to parent ratios should be } \\
>2 \text {. }\end{array}$ \\
\hline & $\begin{array}{l}\text { Rare or threatened species } \\
\text { may be negatively affected } \\
\text { by fires. }\end{array}$ & $\begin{array}{l}\text { The existence of disadvantageous fire regimes } \\
\text { could lead to population declines or local } \\
\text { extinction. }\end{array}$ & Population counts on fixed areas. & $\begin{array}{l}\text { Population declines of }>25 \% \text { in inter- } \\
\text { fire periods. } \\
\text { Post-fire population sizes should be } \\
\text { at least } 75 \% \text { of pre-fire population } \\
\text { levels. }\end{array}$ \\
\hline
\end{tabular}

Source: Adapted from Van Wilgen, B.W., Govender, N., Forsyth, G.G. \& Kraaij, T., 2011, 'Towards adaptive fire management for biodiversity conservation: Experience in South African National Parks', Koedoe 53(2), Art. \#982, 9 pages, http://dx.doi.org/10.4102/koedoe.v53i2.982

FDI, McArthur Forest Fire Danger Index (Noble, I.R., Gill, A.M. \& Bary, G.A.V., 1980, 'McArthur's fire danger meters expressed as equations', Austral Ecology 5, 201-203).

ranging from no manipulation ('natural fire zone management') through selective manipulation ('adaptive interference management') to (attempted) complete control by means of block burning (Seydack 1992; Van Wilgen et al. 1994). The perspective of this study is that of protected area management, with specific reference to the GRNP. The key fire management issues presently faced by the GRNP are, (1) to reconcile ecological and fire hazard reduction requirements (cf. Gill \& McCarthy 1998; Morrison et al. 1996; Van Wilgen et al. 2012), especially in the context of neighbouring commercial plantations and (2) to align invasive alien plant clearing initiatives with fire management strategies to optimise biodiversity conservation and ecosystem service delivery (Kraaij et al. 2011). Here we explore the options for addressing these two main issues within the established ecological constraints.

\section{Fire risk and safety (with emphasis on protecting neighbouring plantations)}

Plantation managers are placing pressure on GRNP managers to adopt a policy of low-intensity burns at short rotations (4-8 years) in fynbos adjacent to plantations to minimise wildfire hazards and damage (Kraaij et al. 2011). Substantial legal claims for damages led to a fire management agreement between the main plantation holding company, Cape Pine (formerly Mountain to Ocean Forestry) and the GRNP for the Tsitsikamma region (Vermeulen et al. 2009). Accordingly, fuel reduction burning is to be undertaken in designated fynbos blocks ( 45 ha -1178 ha in size) located to the north of plantations where indigenous forest does not form a natural buffer between fynbos and plantations (Kraaij et al. 2011). The blocks are strategically placed in 
relation to fire corridors associated with wildfires that burn under hot, dry, bergwind conditions (Geldenhuys 1994) and form two parallel fire belts to be burnt on an 8-year rotation, such that the vegetation in one of the belts would always be $\leq 4$ years of post-fire age. The block burn system is to be further supported by strategically placed fire breaks, as well as controlled fuel reduction burning within plantations, particularly along their boundaries (De Ronde et al. 1990).

However, implementation of this system to date has failed for a number of reasons. The rugged terrain, lack of access roads and natural firebreaks, and dense infestations of invasive alien plants (originating from the plantations), make block burning prohibitively expensive and risky. To date, ecological restrictions on fire season (inherited from winter-rainfall fynbos) combined with fire danger weather restrictions reduced the window of opportunity for prescribed burning to only a few days per year (Van Wilgen \& Richardson 1985). Furthermore, fire legislation - the National Veld and Forest Fire Act (Act No. 101 of 1998) (Republic of South Africa 1998) - acts as a strong deterrent to taking risks with prescribed burning, despite it recognising 'both the ecological role of fire for maintaining healthy ecosystems and the need to reduce the risks posed by fires' (Van Wilgen et al. 2012).

Even if it were possible to implement prescribed burning according to plan (which may be somewhat more plausible with the relaxation of seasonal constraints) (Kraaij 2012), land managers need to realise that fynbos and plantations cannot be fire-proofed (cf. Agee 2002). Assessments of historical fire regimes in the study area (Kraaij, Baard, Cowling, Van Wilgen \& Das 2012) and elsewhere (Keeley, Fotheringham \& Morais 1999; Moritz 2003; Van Wilgen et al. 2010) show that rigid control over fire regimes is largely unattainable. Globally, low levels of fuel-age dependency in fire-prone shrublands and forests imply that fuel reduction burning may not necessarily prevent the occurrence of runaway wildfires (Bessie \& Johnson 1995; Keeley et al. 1999; Moritz 2003; Van Wilgen et al. 2010). The most effective strategy for facilitating fire safety where necessary is to focus effort on strategic locations, bearing in mind that fuel breaks are largely effective at facilitating fire management by providing access for fire fighting activities (Syphard, Keeley \& Brennan 2011). Given the mentioned physical, ecological, economical and political constraints, widescale implementation of prescribed burning is thus likely to remain unattainable (Keeley et al. 1999; Kraaij et al. 2011; Van Wilgen 2009) and ineffective at preventing destructive wildfires (Keeley \& Zedler 2009).

Instead of extensive block burning of fynbos in the GRNP, we recommend a system of largely natural fires and minimum interference, but allowing pro-active fire management measures where or when required ('adaptive interference management') (Seydack 1992). The main focus should be on establishing a network of fire breaks where fynbos abuts plantations or other fire-sensitive land uses. In line with the stipulations of the National Veld and Forest Fire Act (Act No.
101 of 1998) (Republic of South Africa 1998), the location, specifications (clearing method, width and maintenance schedule) and maintenance responsibilities pertaining to fire breaks should be formally agreed upon by neighbouring land managing agencies within the institutional framework of the regional (Southern Cape) Fire Protection Association. In principle, these fire breaks should provide access and relatively safe conditions for fire fighting along boundaries in areas of high fire hazard. Fire breaks have to be practically aligned with topographical features and need to avoid sensitive habitats, such as mountain ridges, rather than strictly follow property boundaries.

The location and specifications of fire breaks (or other proactive fire management interventions) will be dynamic in space and time, tracking changes in the vegetation age mosaic and fire risk distribution. Regular assessments may be required to identify:

- Areas where fires should not burn. These include immature fynbos (<9 years post-fire) (Table 1), areas of disturbed or transformed forest where forest recovery should be facilitated (Watson \& Cameron 2001) and where damage to assets or runaway fires may be anticipated. Such areas should receive priority for intervention during wildfires.

- Areas where fires may be allowed to burn unhindered. These would mainly be inaccessible areas where no immediate threat to assets exists.

- Areas where fires should preferably burn within the next 5 years. These include senescent fynbos (> 40 years old) (Table 1) that requires a burn for rejuvenation, areas where excessive fuel build-up poses a fire hazard to human lives or assets, and disturbed areas (primarily decommissioned plantations) (Kraaij et al. 2011) where fire may facilitate the recovery of fynbos (Holmes \& Richardson 1999). In these areas prescribed burning should be considered.

Adoption of the outlined approach should afford sufficient flexibility to integrate fire management with the dynamic plantation decommissioning and rehabilitation process (Kraaij et al. 2011) and with invasive alien plant management (Roura-Pascual et al. 2009; Van Wilgen 2009).

Other aspects to fire management are preparedness and response or suppression capacity (Van Wilgen et al. 2012). In areas where fires occur seasonally, (high) fire danger season(s) are typically recognised and fire-fighting capacity augmented during this time. Fire managers conventionally regard the fire danger season in the study area to be during autumn-winter (April-October) when rainfall is relatively low and bergwinds often prevail (Geldenhuys 1994; Kraaij et al. 2011; Le Roux 1969). An analysis of the seasonality of fire-prone weather conditions confirmed that fire danger weather peaks in winter (Kraaij, Cowling \& Van Wilgen 2012); although, average conditions are mild yearround compared to those characteristic of fire danger seasons elsewhere in the CFK (Van Wilgen 1984). Furthermore, the historical occurrence of both lightning-ignited and humanignited fires in the study area does not attest to a winter fire 
regime (Kraaij, Baard, Cowling, Van Wilgen \& Das 2012) and large fires may occur at any time of the year, even under low or moderate fire danger conditions (Kraaij, Cowling \& Van Wilgen 2012). Lightning, as a source of ignition, also occurs throughout the year (Kraaij, Cowling \& Van Wilgen 2012). Collectively, these findings suggest that there is no clear fire danger season in the study area that would demand increased preparedness or fire fighting capacity compared to other times of the year.

\section{Fire and management of invasive alien plants}

The first state plantations in the study area were established in 1883 (Kraaij et al. 2011) and the two most widely planted species (Pinus pinaster and Pinus radiata) (Van Wilgen \& Richardson 2012) have become the most problematic invaders in their genus (classed as 'transformers') Richardson et al. 2000) in the study area and elsewhere in the fynbos (Richardson \& Higgins 1998). Key to the invasive success of serotinous pines in fynbos is their response to fire, which is similar to that of proteoids (showing marked spatial and temporal post-fire fluctuations in population sizes). However, pines outperform proteoids in two key facets of demography, that is, seed dispersal and fire-resilience (Richardson \& Higgins 1998). Seeds and pollen of pines are exceptionally well dispersed by wind, whilst isolated pioneers can give rise to colonies by selfing (Richardson \& Higgins 1998). Furthermore, pines have superior fireresilience with comparatively short juvenile periods (c. 5 and 6 years in $P$. radiata and $P$. pinaster, respectively) (Richardson, Cowling \& Le Maitre 1990) and better adult fire-survival ability than most proteoids. Once pines are established, the fynbos may be transformed into a pine forest over two to three fire cycles (Richardson \& Brown 1986). Because the life cycles of serotinous pines (and hakeas) are closely linked to fire, integration of fire and alien plant management strategies is essential (Roura-Pascual et al. 2009).

The conventional methods of managing invasive pines are slashing or hand-pulling of immature saplings, and ringbarking or felling of large mature trees, allowing time for seeds to be released and subsequent burning of new recruits prior to their reaching maturity (Holmes \& Marais 2000; Holmes et al. 2000). Equally, where prescribed burning of fynbos is intended, invader plants require pre-fire treatment. In some cases, options exist for managing invasions by manipulating disturbance regimes like fire cycles (e.g. Esler et al. 2010 for Hakea; Richardson \& Higgins 1998 for Pinus). Unfortunately, potential use of short-rotation fires to control pines is precluded by the fact that juvenile periods of native proteoids in the study area (4-9 years) (Kraaij et al. 2013) are mostly longer than those of pines (see above). However, in fynbos devoid of proteoids (naturally, or as a result of inappropriate past management of fire) and mature pines, application of a single FRI of $<5$ years may, in some instances, provide an inexpensive means of substantially reducing dense infestations of young pine recruits. Otherwise, it would generally be in the interest of invasive plant control to prolong FRIs in order to curb the rate of spread of fire- propagated species such as pines and hakeas (Richardson \& Van Wilgen 1992).

\section{Future research and monitoring needs}

Recent research reported here improved knowledge of the historical fire regime in the study area and how it has changed during the past century. Accurate spatial recording of future fires is important to supply baseline data to inform the design of natural experiments, fire management decisions and planning (Driscoll et al. 2010) and to recognise potential long-term changes in fire regimes (Kraaij, Baard, Cowling, Van Wilgen \& Das 2012). Ongoing monitoring and regular evaluation of fire regime outcomes in terms of agreed thresholds are essential components of the adaptive management cycle, to enable learning and corrective action where necessary. In cases where thresholds are exceeded, consideration needs to be given to management interventions that will drive the system to be within thresholds, or, alternatively, thresholds may be recalibrated where appropriate. Results from the monitoring of ecosystem responses to fires (ecosystem thresholds in Table 1) should inform the calibration of fire pattern thresholds.

The thresholds we proposed for minimum FRI and fire season are first approximations within which fire managers may attempt to resolve the conflicting demands of fire hazard reduction and biodiversity conservation in eastern coastal fynbos. Further research on maturation rates of slowmaturing reseeding plant species and success of post-fire vegetation recovery (Morrison et al. 1995) in diverse habitats would be required to refine these thresholds. Substantial variation, both in flowering status and post-fire recruitment, as well as disparity amongst estimates of minimum FRI based on these measures (Kraaij et al. 2013), emphasise the need to empirically verify Kruger's (1982) rule of thumb conventionally used to establish the lower threshold for FRI. Verification may be conducted by relating pre-fire flowering status of proteoid populations to their post-fire recruitment response at corresponding sites (as for a single site by Kraaij et al. 2013) across various species and habitat types. The mapping of unburnt areas within the outer perimeter of fire boundaries could enable assessments of the extent to which these areas act as refugia and sources of seed for recruitment into the burnt landscape. Further research on plant responses to fire intensity and articulation of the findings into ecological thresholds for fire intensity would also be informative in fynbos generally and, especially, in environments where weather conditions are variable within seasons and the fire season not clearly delineated. Making the link between past fire regimes, as opposed to single fire events, and their ecological outcomes also remains a major challenge. However, the nature of post-fire fynbos assemblages does not solely depend on the fire survival attributes of constituent species and greater understanding is required of the effects of dynamic and competitive interactions between overstorey and understorey species (Cowling \& Gxaba 1990; Vlok \& Yeaton 1999). 
The practicalities of complying with fire legislation in the face of conflicting land management objectives (fire risk vs biodiversity conservation) need to be considered. A legal review should clarify the particular obligations pertaining to the conservation and commercial forestry sectors with respect to fire and invader plant legislation. This should improve compliance and cooperation, whilst averting the need for legal action between roleplayers (Kraaij et al. 2011).

\section{Concluding recommendations}

Recent research aimed to establish what constitutes an acceptable fire regime in eastern coastal fynbos and we accordingly determined ecological thresholds for fire season and return interval. Whilst prescribed burns do not have to be constrained by season in the study area, other constraints remain, most significant of which are safety requirements and the abundance of fire-adapted invasive alien trees. Because large-scale implementation of prescribed burning is unattainable (Keeley et al. 1999; Kraaij et al. 2011; Van Wilgen 2009) and mostly ineffective at ensuring fire safety (Keeley \& Zedler 2009) fire managers need to accept that wildfires will remain dominant. Fire management should be adaptive in nature and focused on, (1) managing wildfires to stay within the proposed thresholds, (2) monitoring to assess actual fire regimes against proposed thresholds or to refine thresholds where appropriate, (3) protecting boundaries between fynbos and fire-sensitive land uses (such as plantations) through collaborative agreements with neighbours and (4) integration of fire and invasive alien plant management, using scarce resources to treat invasive plants and focus prescribed burns in priority areas.

\section{Acknowledgements}

We thank Jan Vlok for conceptual contributions to this study and South African National Parks for exposure to the fire management challenges experienced in the GRNP. The comments of two reviewers resulted in improvements to this manuscript. South African National Parks, Nelson Mandela Metropolitan University, Council for Scientific and Industrial Research (CSIR) and South African Environmental Observation Network funded this study.

\section{Competing interests}

The authors declare that they have no financial or personal relationships which may have inappropriately influenced them in writing this article.

\section{Authors' contributions}

T.K. (Garden Route Scientific Services) largely wrote the manuscript and R.M.C. (Nelson Mandela Metropolitan University) and B.W.v.W. (CSIR Natural Resources and the Environment) made conceptual contributions.

\section{References}

Agee, J.K., 2002, 'The fallacy of passive management. Managing for firesafe forest reserves', Conservation in Practice 3(1), viewed 13 October 2010 from http://www.conbio.org/cip/redesign/article31FPM.cfm, http://dx.doi. org/10.1111/j.1526-4629.2002.tb00023.x
Bessie, W.C. \& Johnson, E.A., 1995, 'The relative importance of fuels and weather on fire behavior in subalpine forests', Ecology 76(3), 747-762. http://dx.doi. org/10.2307/1939341

Biggs, H.C. \& Rogers, K.H., 2003, 'An adaptive system to link science, monitoring and management in practice', in J.T. du Toit, K.H. Rogers \& H.C. Biggs (eds.), The Kruger experience: Ecology and management of savanna heterogeneity, pp. 59-80, Island Press, New York.

Bond, W., 1980, 'Fire and senescent fynbos in the Swartberg, Southern Cape', South African Forestry Journal 114, 68-71. http://dx.doi.org/10.1080/00382167.1980. 9629837

Bond, W.J., 1984, 'Fire survival of Cape Proteaceae - Influence of fire season and seed predators', Vegetatio $56,65-74$.

Bond, W.J., Honig, M. \& Maze, K.E., 1999, 'Seed size and seedling emergence: An allometric relationship and some ecological implications', Oecologia 120, 132136. http://dx.doi.org/10.1007/s004420050841

Bond, W.J., Le Roux, D. \& Erntzen, R., 1990, 'Fire intensity and regeneration of myrmecochorous Proteaceae', South African Journal of Botany 56, 326-330.

Bond, W.J., Vlok, J. \& Viviers, M., 1984, 'Variation in seedling recruitment of Cape Proteaceae after fire', Journal of Ecology 72, 209-221. http://dx.doi. org/10.2307/2260014

Bradstock, R.A. \& Bedward, M., 1992, 'Simulation of the effect of season of fire on post-fire seedling emergence of two Banksia species based on long-term rainfall records', Australian Journal of Botany 40(1), 75-88. http://dx.doi.org/10.1071/ BT9920075

Cowling, R.M. \& Gxaba, T., 1990, 'Effects of a fynbos overstorey shrub on understorey community structure: Implications for the maintenance of community-wide species richness', South African Journal of Ecology 1, 1-7.

Deacon, H.J., Jury, M.R. \& Ellis, F., 1992, 'Selective regime and time', in R.M. Cowling (ed.), The ecology of fynbos. Nutrients, fire and diversity, pp. 6-22, Oxford University Press, Oxford.

De Ronde, N., Goldammer, J.G., Wade, D.D. \& Soares, R.V., 1990, 'Prescribed fire in industrial Pine plantations', in J.G. Goldammer (ed.), Fire in the tropical biota. Ecosystem processes and global challenges, Ecological Studies 84, pp. 216-272, Springer-Verlag, Berlin.

Driscoll, D.A., Lindenmayer, D.B., Bennett, A.F., Bode, M., Bradstock, R.A., Cary, G.J. et al., 2010, 'Fire management for biodiversity conservation: Key research questions al., 2010, 'Fire management for biodiversity conservation: Key research questions
and our capacity to answer them', Biological Conservation 143, 1928-1939. and our capacity to answer them', Biological
$\mathrm{http} / / / \mathrm{dx}$.doi.org/10.1016/j.biocon.2010.05.026

Enright, N.J. \& Lamont, B.B., 1989, 'Seed banks, fire season, safe sites and seedling recruitment in five co-occurring Banksia species', Journal of Ecology 77, 11111122. http://dx.doi.org/10.2307/2260826

Esler, K.J., Van Wilgen, B.W., Te Roller, K.S., Wood, A.R. \& Van der Merwe, J.H., 2010, 'A landscape-scale assessment of the long-term integrated control of an invasive shrub in South Africa', Biological Invasions 12, 211-218. http://dx.doi. org/10.1007/s10530-009-9443-2

Forsyth, G.G. \& Van Wilgen, B.W., 2008, 'The recent fire history of the Table Mountain National Park, and implications for fire management', Koedoe 50(1), 3-9. http:// dx.doi.org/10.4102/koedoe.v50i1.134

Geldenhuys, C.J., 1994, 'Bergwind fires and the location pattern of forest patches in the southern Cape landscape, South Africa', Journal of Biogeography 21, 59-62. http://dx.doi.org/10.2307/2845603

Gill, A.M. \& McCarthy, M.A., 1998, 'Intervals between prescribed fires in Australia: What intrinsic variation should apply?', Biological Conservation 85, 161-169. http://dx.doi.org/10.1016/S0006-3207(97)00121-3

Heelemann, S., Procheş, Ş., Porembski, S. \& Cowling, R.M., 2010, 'Impact of graminoid cover on postfire growth of nonsprouting Protea seedlings in the eastern Fynbos Biome of South Africa', African Journal of Ecology 59, 51-55.

Heelemann, S., Proches, S., Rebelo, A.G., Van Wilgen, B.W., Porembski, S. \& Cowling R.M., 2008, 'Fire season effects on the recruitment of non-sprouting serotinous Proteaceae in the eastern (bimodal rainfall) fynbos biome, South Africa', Austral Proteaceae in the eastern (bimodal rainfall) fynbos biome, South Africa', Austral
Ecology 33(2), 119-127. http://dx.doi.org/10.1111/j.1442-9993.2007.01797.x

Hoffman, M.T., Cramer, M.D., Gillson, L. \& Wallace, M., 2011, 'Pan evaporation and wind run decline in the Cape Floristic Region of South Africa (1974-2005): Implications for vegetation responses to climate change', Climatic Change 109(34), 437-452. http://dx.doi.org/10.1007/s10584-011-0030-z

Holmes, P.M. \& Marais, C., 2000, 'Impacts of alien plant clearance on vegetation in the mountain catchments of the Western Cape', Southern African Forestry Journal 189, 113-117. http://dx.doi.org/10.1080/10295925.2000.9631286

Holmes, P.M. \& Richardson, D.M., 1999, 'Protocols for restoration based on recruitment dynamics, community structure and ecosystem function: Perspectives from South African fynbos', Restoration Ecology 7, 215-230. http://dx.doi.org/10.1046/ j.1526-100X.1999.72015.x

Holmes, P.M., Richardson, D.M., Van Wilgen, B.W. \& Gelderblom, C., 2000, 'The recovery of South African fynbos vegetation following alien woody plant clearing and fire: Implications for restoration', Austral Ecology 25, 631-639. http://dx.doi. org/10.1111/j.1442-9993.2000.tb00069.x

Jefferey, D.J., Holmes, P.M. \& Rebelo, A.G., 1988, 'Effects of dry heat on seed germination in selected indigenous and alien legume species in South Africa, South African Journal of Botany 54, 28-34.

Keeley, J.E. \& Brennan, T.J., 2012, 'Fire-driven alien invasion in a fire-adapted ecosystem', Oecologia 169(4), 1043-1052. http://dx.doi.org/10.1007/s00442012-2253-8, PMid:22286083

Keeley, J.E. \& Zedler, P.H., 2009, 'Large, high-intensity fire events in southern California shrublands: Debunking the fine-grain age-patch model', Ecological Applications 19, 69-94. http://dx.doi.org/10.1890/08-0281.1 
Keeley, J.E., Fotheringham, C.J. \& Morais, M., 1999, 'Reexamining fire suppression impacts on brushland fire regimes', Science 284(5421), 1829-1822. http://dx.doi. impacts on brushland fire regimes', $S$ Ciet
org/10.1126/science.284.5421.1829

Knox, K.J.E. \& Clarke, P.J., 2006, 'Fire season and intensity affect shrub recruitment in temperate sclerophyllous woodlands', Oecologia 149, 730-739. http://dx.doi. org/10.1007/s00442-006-0480-6, PMid:16847616

Kraaij, T., 2012, Fire regimes in eastern coastal fynbos: Drivers, ecology and management, PhD thesis, Department of Botany, Nelson Mandela Metropolitan University, Port Elizabeth

Kraaij, T., Cowling, R.M. \& Van Wilgen, B.W., 2011, 'Past approaches and future challenges to the management of fire and invasive alien plants in the new Garden Route National Park', South African Journal of Science 107(9/10), Art. \#633, 11 pages. http://dx.doi.org/10.4102/sajs.v107i9/10.633

Kraaij, T., Cowling, R.M. \& Van Wilgen, B.W., 2012, 'Lightning and fire weather in eastern coastal fynbos shrublands: Seasonality and long-term trends', International Journal of Wildland Fire. http://dx.doi.org/10.1071/WF11167

Kraaij, T., Cowling, R.M., Van Wilgen, B.W. \& Schutte-Vlok, A-L., 2013, 'Proteaceae juvenile periods and post-fire recruitment as indicators of minimum fire return interval in eastern coastal fynbos', Applied Vegetation Science 16, 84-94. http:// dx.doi.org/10.1111/j.1654-109X.2012.01209.X

Kraaij, T., Baard, J.A., Cowling, R.M., Van Wilgen, B.W. \& Das, S., 2012, 'Historical fire regimes in a poorly-understood, fire-prone ecosystem: Eastern coastal fynbos', International Journal of Wildland Fire. http://dx.doi.org/10.1071/WF11163

Kruger, F.J., 1982, 'Prescribing fire frequencies in Cape fynbos in relation to plant demography', paper presented at the Symposium on the Dynamics and Management of Mediterranean-type Ecosystems, 22-26 June 1981, San Diego, California. General Technical Report PSW-58, pp. 118-122, Pacific Southwest Forest and Range Experiment Station, Forest Service and Department of Agriculture, Berkeley.

Kruger, F.J., 1984, 'Effects of fire on vegetation structure and dynamics', in P. de V. Booysen \& N.M. Tainton (eds.), Ecological effects of fire in South African ecosystems, Ecological Studies 48, pp. 219-243, Springer-Verlag, Berlin. http:// dx.doi.org/10.1007/978-3-642-69805-7_10

Kruger, F.J. \& Bigalke, R.C., 1984, 'Fire in fynbos', in P. de V. Booysen \& N.M. Tainton (eds.), Ecological effects of fire in South African ecosystems, Ecological Studies 48 , pp. 67-114, Springer-Verlag, Berlin. http://dx.doi.org/10.1007/978-3-64269805-7_5

Kruger, F.J. \& Lamb, A.J., 1978, Conservation of the Kogelberg State Forest. Preliminary assessment of the effects of management from 1967 to 1978, Jonkershoek Forestry Research Centre, Report 79-02, Stellenbosch.

Le Roux, P.J., 1969, 'Brandbestryding in suid-Kaapland met spesiale verwysing na chemiese metodes van beheer [Fire fighting in the Southern Cape with special reference to chemical methods of control]', MSc thesis, Department of Forestry, reference to chemical meth
University of Stellenbosch.

Lloret, F., Pausas, G. \& Vilà, M., 2003, 'Responses of Mediterranean plant species to different fire frequencies in Garraf Natural Park (Catalonia, Spain): Field to different fire frequencies in Garraf Natural Park (Catalonia, Spain): Field
observations and modelling predictions', Plant Ecology 167, 223-235. http:// observations and modelling predictions,
dx.doi.org/10.1023/A:1023911031155

Midgley, J.J., 1989, 'Season of burn of serotinous fynbos Proteaceae: A critical review and further data', South African Journal of Botany 55, 165-170.

Midgley, J.J. \& Viviers, M., 1990, 'The germination of seeds from heated serotinous cones of eight shrubland species', South African Forestry Journal 155, 5-9. http:// dx.doi.org/10.1080/00382167.1990.9629064

Moritz, M.A., 2003, 'Spatiotermporal analysis of controls on shrubland fire regimes: Age dependency and fire hazard', Ecology 84(2), 351-361. http://dx.doi. org/10.1890/0012-9658(2003)084[0351:SAOCOS]2.0.CO;2

Morrison, D.A., Buckney, R.T. \& Bewick, B.J., 1996, 'Conservation conflicts ove burning bush in south-eastern Australia', Biological Conservation 76, 167-175. http://dx.doi.org/10.1016/0006-3207(95)00098-4

Morrison, D.A., Cary, G.J., Pengelly, S.M., Ross, D.G., Mullins, B.J., Thomas, C.R. et al., 1995, 'Effects of fire frequency on plant-species composition of sandstone communities in the Sydney region: Inter-fire interval and time-since-fire', Australian Journal of Ecology 20, 239-147. http://dx.doi.org/10.1111/j.1442-9993.1995. tb00535.x

Myers, N., Mittermeier, R.A., Mittermeier, C.G., Da Fonseca, G.A.B. \& Kent, J., 2000 'Biodiversity hotspots for conservation priorities', Nature 403, 853-858. http:// dx.doi.org/10.1038/35002501, PMid:10706275

Noble, I.R., Gill, A.M. \& Bary, G.A.V., 1980, 'McArthur's fire danger meters expressed as equations', Austral Ecology 5, 201-203.

Raimondo, D., Von Staden, L., Foden, W., Victor, J.E., Helme, N.A., Turner, R.C. et al (eds.), 2009, 'Red List of South African plants', Strelitzia 25, South African National Biodiversity Institute, Pretoria.

Rebelo, A.G., Boucher, C., Helme, N., Mucina, L. \& Rutherford, M.C., 2006, 'Fynbos biome', in L. Mucina \& M.C. Rutherford (eds.), The vegetation of South Africa, Lesotho and Swaziland, Strelitzia 19, pp. 158-159, South African National Lesotho and Swaziland, Strelitzersity Institute, Pretoria.
Biodis

Republic of South Africa, 1998, National Veld and Forest Fire (Act No. 101 of 1998), Government Gazette 401(19515), Government Printers, Cape Town.
Richardson, D.M. \& Brown, P.J., 1986, 'Invasion of mesic mountain fynbos by Pinus radiata', South African Journal of Botany 52, 529-535.

Richardson, D.M. \& Higgins, S.I., 1998, 'Pines as invaders in the southern hemisphere', in D.M. Richardson (ed.), Ecology and biogeography of Pinus, pp. 450-473, Cambridge University Press, Cambridge.

Richardson, D.M. \& Van Wilgen, B.W., 1992, 'Ecosystem, community and species response to fire in mountain fynbos: Conclusions from the Swartboskloof experiment', in B.W. van Wilgen, D.M. Richardson, F.J. Kruger \& H.J. van Hensbergen (eds.), Fire in South African mountain fynbos: Species, community and ecosystem response in Swartboskloof, Ecological Studies 93, pp. 273-284, Springer-Verlag, Berlin.

Richardson, D.M., Cowling, R.M. \& Le Maitre, D.C., 1990, 'Assessing the risk of invasive success in Pinus and Banksia in South African mountain fynbos', Journal of Vegetation Science 1, 629-642. http://dx.doi.org/10.2307/3235569

Richardson, D.M., Pysek, P., Rejmanek, M., Barbour, M.G., Panetta, D.F. \& West, C.J., 2000, 'Naturalization and invasion of alien plants - Concepts and definitions',
Diversity \& Distributions 6, 93-107. http://dx.doi.org/10.1046/j.1472Diversity \& Dist

Roura-Pascual, N., Richardson, D.M., Krug, R.M., Brown, A., Chapman, R.A., Forsyth, G.G. et al., 2009, 'Ecology and management of alien plant invasions in South African fynbos: Accommodating key complexities in objective decision making' Biological Conservation 142(8), 1595-1604. http://dx.doi.org/10.1016/j. biocon.2009.02.029

Schulze, R.E., 1997, 'Climate', in R.M. Cowling, D.M. Richardson \& S.M. Pierce (eds.), Vegetation of southern Africa, pp. 21-42, Cambridge University Press, Cambridge.

Seydack, A.H.W., 1992, 'Fire management options in fynbos mountain catchment areas', South African Forestry Journal 161, 53-58. http://dx.doi.org/10.1080/00 382167.1992.9630425

Seydack, A.H.W., Bekker, S.J. \& Marshall, A.H., 2007, 'Shrubland fire regime scenarios in the Swartberg Mountain Range, South Africa: Implications for fire management', International Journal of Wildland Fire 16, 81-95. http://dx.doi. management', Internation
org/10.1071/WF06015

Syphard, A.D., Keeley, J.E. \& Brennan, T.J., 2011, 'Comparing the role of fuel breaks across southern California national forests', Forest Ecology and Management 261 2038-2048. http://dx.doi.org/10.1016/j.foreco.2011.02.030

Thuiller, W., Slingsby, J.A., Privett, S.D.J. \& Cowling, R.M., 2007, 'Stochastic species turnover and stable coexistence in a species-rich, fire-prone plant community', PLOS ONE 2(9), e938. http://dx.doi.org/10.1371/journal.pone.0000938

Van Wilgen, B.W., 1984, 'Fire climates in the southern and western Cape Province and their potential use in fire control management', South African Journal of Science their potential $358-362$.

Van Wilgen, B.W., 2009, 'The evolution of fire and invasive alien plant management practices in fynbos', South African Journal of Science 105, 335-342.

Van Wilgen, B.W. \& Richardson, D.M., 1985, 'Factors influencing burning by prescription in mountain fynbos catchment areas', South African Forestry Journal 134, 22-32. http://dx.doi.org/10.1080/00382167.1985.9629590

Van Wilgen, B.W. \& Richardson, D.M., 2012, 'Three centuries of managing introduced conifers in South Africa: Benefits, impacts, changing perceptions and conflict resolution', Journal of Environmental Management 106, 56-68. http://dx.doi. org/10.1016/j.jenvman.2012.03.052, PMid:22562012

Van Wilgen, B.W. \& Viviers, M., 1985, 'The effect of season of fire on serotinous Proteaceae in the Western Cape and the implications for fynbos management',
South African Forestry Journal 133, 47-53. http://dx.doi.org/10.1080/00382167 South African For
.1985 .9629574

Van Wilgen, B.W., Forsyth, G.G. \& Prins, P., 2012, 'The management of fire-adapted ecosystems in an urban setting: The case of Table Mountain National Park, South
Africa', Ecology and Society 17(1), 8. http://dx.doi.org/10.5751/ES-04526-170108

Van Wilgen, B.W., Richardson, D.M. \& Seydack, A.H.W., 1994, 'Managing fynbos for biodiversity: Constraints and options in a fire-prone environment', South African Journal of Science 90, 322-329.

Van Wilgen, B.W., Govender, N., Forsyth, G.G. \& Kraaij, T., 2011, 'Towards adaptive fire management for biodiversity conservation: Experience in South African National
Parks', Koedoe 53(2), Art. \#982, 9 pages, http://dx.doi.org/10.4102/koedoe. Parks', Koed
v53i2.982

Van Wilgen, B.W., Forsyth, G.G., De Klerk, H., Das, S., Khuluse, S. \& Schmitz, P., 2010, 'Fire management in Mediterranean-climate shrublands: A case study from the Cape fynbos, South Africa', Journal of Applied Ecology 47(3), 631-638. http:// Cape fynbos, South Africa', Journal of Applied
dx.doi.org/10.1111/j.1365-2664.2010.01800.

Vermeulen, W.J., Van der Merwe, C.J., Seydack, A.H.W., Baard, J., Cunningham, H., Kraaij, T. et al., 2009, Fire management system for the Tsitsikamma mountain catchment area, South African National Parks, Knysna.

Vlok, J.H.J. \& Yeaton, R.I., 1999, 'The effect of overstorey proteas on plant species richness in South African mountain fynbos', Diversity \& Distributions 5, 213-222. http://dx.doi.org/10.1046/j.1472-4642.1999.00055.x

Watson, L.H. \& Cameron, M.J., 2001, 'The influence of fire on a southern Cape mountain forest', South African Forestry Journal 191, 39-42. http://dx.doi.org/10 .1080/20702620.2001.10434149

Wilson, A.M., Latimer, A.M., Silander, J.A. Jnr, Gelfand, A.E. \& De Klerk, H., 2010, 'A hierarchical Bayesian model of wildfire in a Mediterranean biodiversity hotspot: Implications of weather variability and global circulation', Ecological Modelling 221, 106-112. http://dx.doi.org/10.1016/j.ecolmodel.2009.09.016 